\title{
NASKAH AKADEMIK RANCANGAN PERATURAN DAERAH TENTANG PERLINDUNGAN LAHAN PERTANIAN PANGAN BERKELANJUTAN
}

M Chairul Basrun Umanailoํㅜ, Annisa Retrofilia Umanailo ${ }^{1}$, and Askar Daffa Sophia

Umanailo $^{1}$

${ }^{1}$ Affiliation not available

December 21, 2020

\section{Hosted file}

NASKAH AKADEMIK PERLINDUNGAN LAHAN PERTANIAN PANGAN BERKELANJUTAN.pdf available at https://authorea.com/users/310886/articles/498957-naskah-akademik-rancangan-peraturandaerah-tentang-perlindungan-lahan-pertanian-pangan-berkelanjutan 